\title{
La colina del buey (EUNA 2019), de José León Sánchez: Un relato sobre la minería y la condición humana.
}

\section{La colina del Buey ["The Hill of the Ox"], by José León Sánchez. A Story about Mining and the human condition}

\author{
Marybel Soto-Ramírez \\ Instituto de Estudios Latinoamericanos \\ Universidad Nacional \\ Costa Rica
}

José León Sánchez es un escritor consolidado internacionalmente. $\mathrm{Si}$ bien su referencia inmediata es por la célebre La isla de los hombres solos, la producción editorial de don José León es muy amplia y variada; conviene conocerla, disfrutarla y, sobre todo, analizarla. Dentro de esa producción, por la cual se le ha reconocido en México como uno de los mejores escritores latinoamericanos de todos los tiempos, hay una

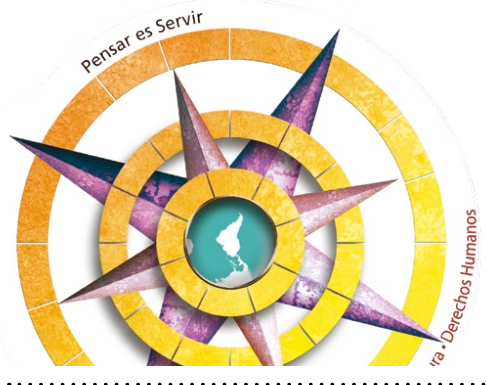

Doi: https://doi.org/10,15359/tdna.36-68.10 obra muy interesante que, hasta hace poco, no se lograba conseguir en el mercado nacional. Se trata de $\mathrm{La} \mathrm{co}$ lina del buey. Es una novela que se desarrolla en Montes de Oro, en los poblados de Abangares, zona minera en el pacífico central de Costa Rica, de cuya actividad más efervescente en la primera mitad del siglo XX aún quedan vestigios en los socavones $\mathrm{y}$ galerías de los cerros.

La colina del buey recupera la historia cotidiana de los mineros, no exenta del drama de la condición humana al límite: el alcoholismo, los juegos, la codicia, las riñas, la explotación y, también, el amor, la lucha por arrancar a la veta el destello del oro en 
sus sórdidas rutas de golpe de suerte. Hoy, cuando la discusión asociada a megaproyectos de explotación minera unidos al gran capital internacional ha resurgido y ha puesto una constante tensión entre la protección ambiental y las regulaciones de tipo político, con sus muchas aristas, este relato de don José León Sánchez es pertinente, oportuno y fresco. Quizá en su lectura se reconozcan algunos de los más serios peligros que la codicia asociada con la extracción de metal puede tener en los seres humanos, primeramente, y en los poblados adyacentes, por extensión.

Descubrir a Manuel Miranda Miranda, conocido como Picahueso, el personaje principal, coadyuvará a la sensibilización sobre esta actividad pujante a inicios del siglo XX; él nos lleva de la mano y, en sus propias palabras, brinda testimonio, desde su infancia en San Ramón Nonato, sobre los exilios como pena de destierro impuesta por el concejo municipal, sobre las casas, los lavaderos de ropa a orillas de los ríos, sobre su visión de San José y los nombres de las minas....
Leer a José León Sánchez es una experiencia única de contraste de la condición humana, de la lucha contra todo para sobrevivir y lograr surgir. Las nuevas generaciones encontrarán en esta novela un testimonio de una época desconocida y las personas más maduras en años descubriremos una vida de un ser humano que osciló entre el oro negro y el oro verde a lo largo de la geografía costarricense y que, en su caminar, dejó testimonio de ser "borracho, peleador y enamorado. Pero honrado y muy buen macho".

La colina del buey es una nueva edición de la Editorial Universidad Nacional. Con ella y las próximas obras que vendrán del Sr. José León Sánchez, se honra el legado de este costarricense galardonado con el Premio Nacional de Cultura Magón de nuestro país en 2017 y con un sinnúmero más de reconocimientos internacionales a lo largo de su prolífica vida, en el oficio de escritor. 